\title{
Synthesis, structures and catalytic activity of homo- and heteroleptic ketoiminate zinc complexes in lactide polymerization
}

\author{
Phillip Steiniger, ${ }^{[a]}$ Pascal M. Schäfer ${ }^{[b]}$ Christoph Wölper, ${ }^{[a]}$, Johanna Henkel, ${ }^{[b]}$ Agnieszka N. \\ Ksiazkiewicz, ${ }^{[c, d]}$ Andrij Pich, ${ }^{[c, d]}$ Sonja Herres-Pawlis ${ }^{[b]}$ and Stephan Schulz ${ }^{*[a]}$
}

Dedicated to Prof. Dr. K. Jurkschat on the occasion of his retirement.

\begin{abstract}
The heteroleptic complex LZnEt $(\mathrm{L}=$ MeNacac $=$ $\mathrm{MeNC}(\mathrm{Me}) \mathrm{CHC}(\mathrm{Me}) \mathrm{O}$ 1) containing the sterically less demanding $\mathrm{N}, \mathrm{O}$-chelating ketoiminate (MeNacac) ligand was synthesized by reaction of $\mathrm{ZnEt}_{2}$ with an equimolar amount of $\mathrm{MeNacacH}$, whereas the reaction with two equivalents $\mathrm{MeNacacH}$ gave the homoleptic complex $\mathrm{L}_{2} \mathrm{Zn} 5$. 1 reacts with $\mathrm{ArOH}\left(\mathrm{Ar}=2,6-\mathrm{Me}_{2}-\mathrm{Ph}\right)$ with ethane elimination and formation of LZnOAr (2). Addition of the Lewis base dmap (dmap $=4$-dimethylamino pyridine) to $\mathbf{1}$ and $\mathbf{2}$ yielded the corresponding Lewis acid-base adducts dmap-Zn(L)Et 3 and dmap$\mathrm{Zn}(\mathrm{L}) \mathrm{OAr}$ 4. 1 - $\mathbf{5}$ were characterized by heteronuclear NMR and IR spectroscopy, elemental analysis and single crystal $\mathrm{X}$-ray diffraction $(\mathbf{1}$ - 3, 5). Their technical application as catalysts in ring-opening polymerization (ROP) of rac-lactide in a $\mathrm{CD}_{2} \mathrm{Cl}_{2}$ solution at ambient temperature was investigated. 2 and $\mathbf{3}$ show the highest activities, whereas those of $\mathbf{1}$ and $\mathbf{5}$ are substantially lower. $\mathbf{2}$ and $\mathbf{3}$ polymerize rac-lactide (90\% conversion) within 140 (3) and 180 minutes (2), respectively. In contrast, 4 could only be investigated in bulk polymerization reactions due to its very poor solubility in common organic solvents. These studies proved that $\mathbf{4}$ is active in bulk polymerization, converting $93 \%$ lactide to PLA at $140{ }^{\circ} \mathrm{C}$ within 20 minutes.
\end{abstract}

\section{Introduction}

In times of fast growing humankind and resource scarcity, mineral oil-based plastics become more and more unattractive. Although common plastics are economically preferred, ${ }^{[1]}$ polymers based on natural feedstock such as poly(lactide) (PLA) have the enormous advantage of biodegradability. Therefore, PLA is very attractive to the packaging industry and makes it also suitable for medical applications such as wound dressings, stents and tissue

[a] M.Sc. P. Steiniger, Dr. C. Wölper and Prof. Dr. S. Schulz Faculty of Chemistry and Center for Nanointegration DuisburgEssen (Cenide), University of Duisburg-Essen Universitätsstr. 5-7, S07 S03 C30, 45117 Essen (Germany) E-mail: stephan.schulz@uni-due.de Homepage: https://www.uni-due.de/ak_schulz/index_en.php

[b] M.Sc. P. M. Schäfer, B.Sc. J. Henkel, Prof. Dr. S. Herres-Pawlis Institute of Inorganic Chemistry, RWTH Aachen University, Landoltweg 1, 52074 Aachen, Germany

[c] M.Sc. A. N. Ksiakiewicz, Prof. Dr. A. Pich Institute of Technical and Macromolecular Chemistry, RWTH Aachen University

Worringerweg 2, 52074 Aachen, Germany

[d] DWI - Leibniz Institute for Interactive Materials e. V. Forckenbeckstraße 50, 42074 Aachen, Germany

Supporting information for this article is given via a link at the end of the document.

engineering. ${ }^{[2]}$ The industrially preferred catalyst in the synthesis of PLA is $\mathrm{Sn}(\mathrm{Oct})_{2}$. $\mathrm{Sn}(\mathrm{Oct})_{2}$ possesses the FDA approval but its toxicity for cells has definitively been proven. ${ }^{[3]}$ Since the complete extraction of residual tin from the polymer is rather impossible, there is a strong demand for alternative metal-based catalysts. ${ }^{[4]}$ In recent years, several groups reported on metal complexes based on $s$-block, ${ }^{[5]} p$-block, ${ }^{[6]} d$-block, ${ }^{[7]}$ and $f$-block metals, ${ }^{[8]}$ respectively, which have been found active in ring-opening polymerization (ROP) of lactide..$^{[9]}$ Among these, zinc complexes have received particular attention since they have shown outstanding catalytic performances in melt processes and in solution-based processes. ${ }^{[10]}$ So far, several heteroleptic zinc complexes $\mathrm{LZnX}$ containing monoanionic alkyl, ${ }^{[11]}$ alkoxy, ${ }^{[12]}$ halide,$^{[13]}$ and amide substituents $(X)^{[14]}$ were successfully tested in ROP of lactide. Moreover, complexes containing chelating organic substituents such as scorpionate,${ }^{[15]}$ Schiff-base, ${ }^{[16]}$ salen and other ligands have been investigated in ROP of lactide. ${ }^{[17]} \beta-$ diketiminate zinc complexes are of particular interest, and they were investigated experimentally ${ }^{[18]}$ and by means of quantum chemical calculations. ${ }^{[19]} \beta$-diketiminate zinc complexes are welldefined living initiators for the ROP of $(\mathrm{S}, \mathrm{S})$-lactide, rac-lactide and meso-lactide. Their activity was found to strongly depend on their structure in solution, and in particular weakly bonded dimeric species exhibited high activities. Moreover, the N-substituents have a crucial influence on the stereoselectivity and the polymerization rate. ${ }^{[20]}$ Recently, Williams et al. reported homobimetallic zinc catalysts with record-high turnover frequency (TOF) values up to $60000 \mathrm{~h}^{-1}$ at ambient temperature. ${ }^{[10 \mathrm{a}]} \mathrm{In}$ addition to $\beta$-diketiminate complexes, ketoiminate zinc complexes have also been explored in lactide polymerization ${ }^{[21]}$ and the influence of both steric and electronic variations of the $\mathrm{N}$ substituents on the catalytic activity was demonstrated. ${ }^{[22]}$ Moreover, the catalytic activity of zinc complexes supported by tridentate N,N',O-chelating diamino- and aminoiminophenolate ligands was shown to depend on the nature of the central $\mathrm{N}$-donor function, since tertiary amines were less active compared to complexes containing a central secondary amine or imine group. ${ }^{[23]}$

We are generally interested in the synthesis, structure and reactivity of homo- and heteroleptic zinc complexes containing $\mathrm{N}, \mathrm{N}^{\prime}$-chelating ligands such as $\beta$-diketiminates ${ }^{[24]}$ and amidinates, ${ }^{[25]} \mathrm{O}, \mathrm{O}^{\prime}$-chelating carboxylates ${ }^{[26]}$ and $\mathrm{N}, \mathrm{O}$-chelating ketoiminates. ${ }^{[27]}$ The catalytic activity of bidentate $\beta$ diketiminate ${ }^{[10 \mathrm{~d}]}$ and carboxylate zinc complexes ${ }^{[10 \mathrm{~g}]}$ as well as of tridentate ketoiminate zinc complexes in ROP of rac-lactide was also studied by us and the crucial role of the side-arm donor group on the catalytic activity was revealed. ${ }^{[11]}$ Herein, we report on the synthesis of heteroleptic (1 - 4) and homoleptic (5) ketoiminate zinc complexes containing the smallest possible alkyl group $(\mathrm{Me})$ bound to the $\mathrm{N}$-atom of the ketoiminate ligand. In contrast to 
known ketoiminate zinc catalysts, which are almost exclusively kinetically stabilized by bulky organic substituents, the zinc atoms in the new heteroleptic complexes $\mathbf{1 - 4}$ are not protected by any sterically demanding group. The use of sterically less demanding substituents is expected to favor the coordination of the monomer (lactide) to the Lewis-acidic metal center, which is the initial step in the polymerization of lactide.

\section{Results and Discussion}

Synthesis and characterization. The reaction of ketoimine $\mathrm{LH}$ $[\mathrm{L}=\mathrm{MeNacac}=\mathrm{MeNC}(\mathrm{Me}) \mathrm{CHC}(\mathrm{Me}) \mathrm{O}]$ with an equimolar amount of diethyl zinc in THF at $-60^{\circ} \mathrm{C}$ occurred with elimination of ethane and formation of the heteroleptic zinc complex LZnEt 1 in good yields, whereas the analogous reaction with 0.5 equivalents of $\mathrm{ZnEt}_{2}$ yielded the homoleptic complex $\mathrm{L}_{2} \mathrm{Zn} 5$. Reaction of 1 with 2,6-dimethylphenol ( $\mathrm{HOAr}, \mathrm{Ar}=2,6-\mathrm{Me}_{2}-\mathrm{C}_{6} \mathrm{H}_{3}$ ) gave the heteroleptic complex LZnOAr 2. The Lewis-acidic character of 1 and 2 was revealed by reactions with equimolar amounts of 4dimethylamino pyridine (dmap), yielding almost quantitatively the corresponding dmap-stabilized complexes (dmap)Zn(L)Et 3 and (dmap)Zn(L)OAr 4 (Scheme 1). In contrast, 5 failed to react with dmap due to the presence of two N,O-chelating ligands.

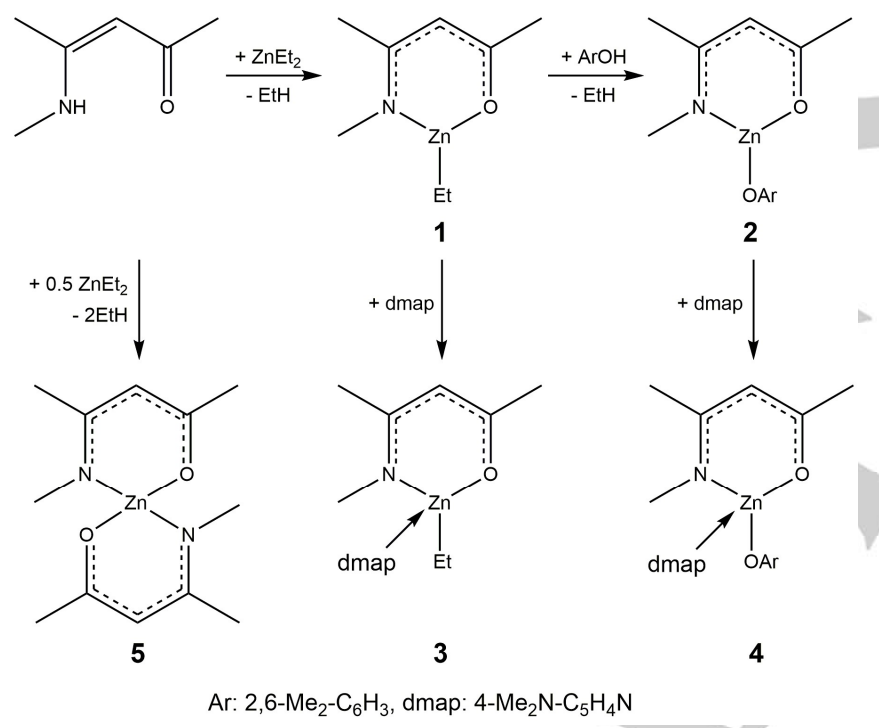

Scheme 1: Synthesis of 1-5.

1 - 5 were characterized by elemental analysis, IR spectroscopy and heteronuclear $\left({ }^{1} \mathrm{H},{ }^{13} \mathrm{C}\right)$ NMR spectroscopy. ${ }^{1} \mathrm{H}$ NMR spectra each showed the expected four singlets due to the backbone C$\mathrm{H}$ and three Me groups of the ketoiminate ligand in the expected $1: 3: 3: 3$ relative intensity as well as the Et (1), OR (2) and dmap groups $(3,4)$ bonded to the zinc atom.

Single crystals of 1, 2, 3 and 5 were obtained from solutions in THF upon storage at $-30{ }^{\circ} \mathrm{C}$ for $12 \mathrm{~h}$. Table 1 summarizes selected bond lengths and angles of $\mathbf{1}-\mathbf{3}$ and $\mathbf{5} . \mathbf{1}$ crystallizes in the monoclinic space group $C 2 / c$ (Fig. 1) with the molecule placed on special position $4 d$ (centre of inversion). The $\mathrm{Zn}(1)$ atom is coordinated by the $\mathrm{N}, \mathrm{O}$-chelating MeNacac ligand and the $\mathrm{Et}$ group. An additional bond to the $\mathrm{O}^{\prime}$ atom of the symmetry equivalent MeNacac results in the formation of a $\mathrm{Zn}_{2} \mathrm{O}_{2}$ ring and a step-like conformation of the molecule with an angle of $68.45(4)^{\circ}$ between the best planes of the adjacent rings. The $\mathrm{C}_{3} \mathrm{NO}$ backbone of the MeNacac ligand is flat (r.m.s. deviation from best plane $0.0199 \AA$ ) and the zinc atom is slightly off-set $(0.5089(11) \AA)$ away from the symmetry equivalent ligand, resulting in a strongly distorted tetrahedral environment of the zinc atom. The bonds to the heteroatoms are roughly perpendicular $\left(83.40(3)\right.$ to $102.49(3)^{\circ}$, Table 1$)$, while the $\mathrm{C}_{\mathrm{Et}} \mathrm{Zn}-\mathrm{N} / \mathrm{O}$ bond angles are significantly larger than the tetrahedral angle $\left(113.29(4)\right.$ to $\left.129.83(4)^{\circ}\right)$. The $\mathrm{Zn}-\mathrm{N}$ and $\mathrm{Zn}-\mathrm{O}$ bonds within the asymmetric unit of 1 are (within s.u.) equal to the mean values derived from the CSD for $\mathrm{Zn}$ ketiminato complexes. ${ }^{[28]}$ The $\mathrm{Zn}-\mathrm{O}$ bond lengths within the $\mathrm{Zn}_{2} \mathrm{O}_{2}$ ring (2.1243(8) $\AA$ ) agree with those reported for tricyclic $\mathrm{Zn}$ ketiminato complexes, ${ }^{[29]}$ while a $\mathrm{Zn}$ complex containing a ketiminato ligand with an additional hemilabile side-arm donor shows shorter $\mathrm{Zn}-\mathrm{O}$ bond lengths (2.0781(12) and 2.0904(12) $\AA) .{ }^{[11]}$

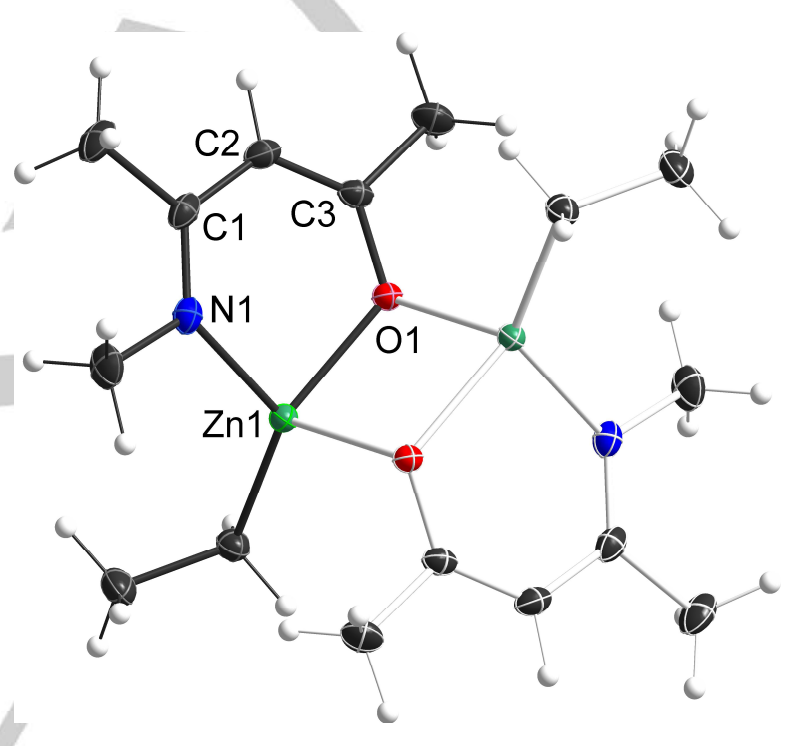

Figure 1. Solid state structure of $\mathbf{1}$, thermal ellipsoids are shown at $50 \%$ probability levels. Symmetry generated part displayed in pale colors.

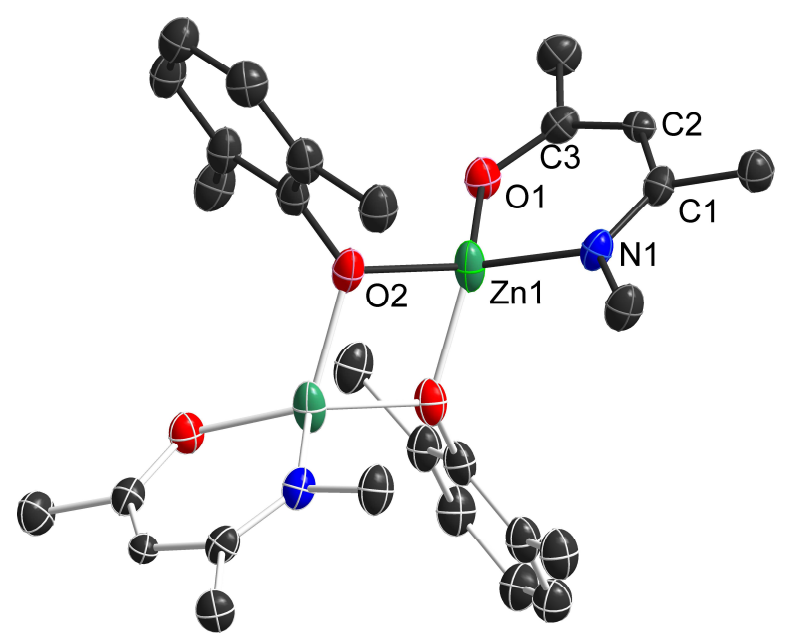

Figure 2. Solid state structure of 2, thermal ellipsoids are shown at $50 \%$ probability levels. Symmetry generated part displayed in pale colors. Disordered solvent and hydrogen atoms omitted for clarity. 
Compound 2 crystallizes in the monoclinic space group C2/c with the molecule place on a two-fold rotational axis and disordered THF (total occupancy $75 \%$ ), resulting in a $C_{2}$ symmetric dimer with phenolate ligands bridging the two $\mathrm{Zn}$ atoms (Fig. 2).

Table 1. Central bond lengths $(\AA)$ and bond angles $\left({ }^{\circ}\right)$ of $\mathbf{1}$ - $\mathbf{3}$ and 5

\begin{tabular}{|c|c|c|c|c|}
\hline & 1 & 2 & 3 & 5 \\
\hline Zn1-O1 & $2.0153(8)$ & $1.920(2)$ & $1.9817(6)$ & $1.9574(10)^{[a]}$ \\
\hline Zn1-N1 & $2.0100(9)$ & $1.952(3)$ & $2.0230(8)$ & $1.9713(11)^{[b]}$ \\
\hline $\mathrm{Zn} 1-\mathrm{O} 2$ & - & $1.975(2)$ & - & - \\
\hline Zn1-O2' & - & $1.984(2)$ & - & - \\
\hline $\mathrm{Zn} 1-\mathrm{C}_{\mathrm{Et}}$ & $1.9780(11)$ & - & $1.9952(9)$ & - \\
\hline Zn1-01' & $2.1243(8)$ & - & - & $1.9574(10)^{[\mathrm{a}]}$ \\
\hline Zn1-NDMAP & - & - & $2.1121(7)$ & - \\
\hline Zn1-N1' & - & - & - & $1.9713(11)^{[b]}$ \\
\hline O1-Zn1-N1 & $92.25(3)$ & $100.45(10)$ & $94.05(3)$ & $96.47(4)$ \\
\hline O1-Zn1-O2 & - & $120.51(9)$ & - & - \\
\hline $\mathrm{N} 1-\mathrm{Zn} 1-\mathrm{O} 2$ & - & $121.61(10)$ & - & - \\
\hline O1-Zn1-N & - & - & $95.52(3)$ & - \\
\hline O1-Zn1-C $\mathrm{Et}_{\mathrm{t}}$ & $129.83(4)$ & - & $129.57(4)$ & - \\
\hline $\mathrm{N} 1-\mathrm{Zn} 1-\mathrm{C}_{\mathrm{Et}}$ & $125.84(4)$ & - & $118.05(4)$ & \\
\hline O1'-Zn1-N1 & $102.49(3)$ & & - & $5(4)$ \\
\hline $\mathrm{O} 1{ }^{\prime}-\mathrm{Zn} 1-\mathrm{C}_{\mathrm{Et}}$ & $113.29(4)$ & - & - & . \\
\hline O1'-Zn1-O1 & $83.40(3)$ & - & - & (6) \\
\hline O2'-Zn1-O1 & - & $119.03(10)$ & - & \\
\hline N1-Zn1-O2' & - & $115.33(10)$ & - & - \\
\hline O2-Zn1-O2' & - & $80.70(10)$ & - & - \\
\hline $\mathrm{N} 1{ }^{\prime}-\mathrm{Zn} 1-\mathrm{N} 1$ & - & - & - & $128.47(7)$ \\
\hline $\mathrm{N}_{\mathrm{DMAP}}-\mathrm{Zn} 1-\mathrm{N} 1$ & - & - & $106.32(3)$ & \\
\hline NDMAP-Zn1-CEt & - & - & $109.56(3)$ & \\
\hline $\mathrm{N}_{\mathrm{DMAP}}-\mathrm{Zn} 1-\mathrm{O} 1$ & - & & $95.52(3)$ & - \\
\hline
\end{tabular}

[a] equal because of symmetry equivalence, [b] equal because of symmetry equivalence

The $\mathrm{Zn}$ atom in $\mathbf{2}$ is coordinated by a chelating MeNacac ligand to complete its slightly distorted tetrahedral coordination sphere (bond angles in the range form $80: 70(10)^{\circ}$ to $121: 61(10)^{\circ}$ ). The six-membered $\mathrm{ZnNC}_{3} \mathrm{O}$ ring is planar (r.m.s. deviation from best plane $0.0219 \AA$ ) and adopts a perpendicular orientation to the central $\mathrm{Zn}_{2} \mathrm{O}_{2}$ four-membered ring (angle between best planes $\left.87.74(6)^{\circ}\right)$. The latter ring is also planar (r.m.s. from best plane $0.0055 \AA$ ). The plane of the phenolate substituent is perpendicular to both the four-membered (angle between best planes $85.42(9)^{\circ}$ ) and the six-membered ring (angle between best planes $89.88(9)^{\circ}$ ). The $\mathrm{Zn}-\mathrm{N}$ and $\mathrm{Zn}-\mathrm{O}$ bonds are substantially shorter compared to those in 1 , possibly resulting from strong intramolecular hydrogen bonds from the methyl groups of the phenolate to the heteroatoms of the MesNacac ligand.

3 crystallizes in the triclinic space group $P-1$ with the molecule placed on the general position (Fig. 3). The zinc atom (Zn1) is coordinated to the MeNacac ligand in the expected N,O-chelating mode as well as one additional ethyl group and one dmap molecule, resulting in a total coordination number of four.

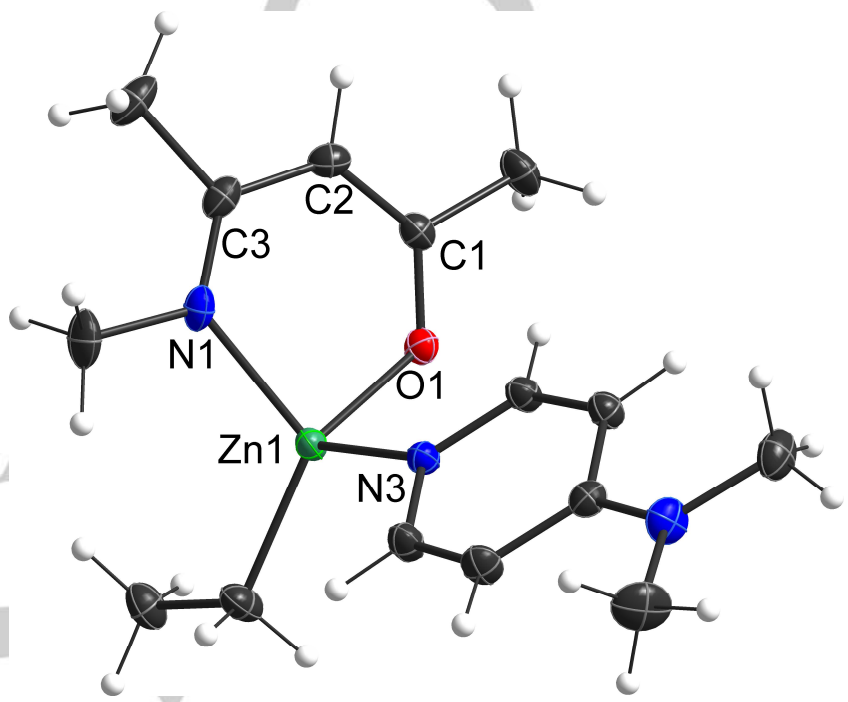

Figure 3. Solid state structure of $\mathbf{3}$, thermal ellipsoids are shown at $50 \%$ probability levels.

The most notable distortion of the tetrahedral environment of the zinc atom is its shift towards one of the planes of the tetrahedron (located $0.4872(5) \AA$ off the $\mathrm{N} 1 / \mathrm{O} 1 / \mathrm{C}_{\mathrm{Et}}$ plane) and the coordination mode at the zinc atom can thus rather been described as trigonalbipyramidal with one empty coordination site. The zinc atom and the $\mathrm{NC}_{3} \mathrm{O}$ backbone of the MeNacac ligand form a planar sixmembered ring (r.m.s. deviation from best plane $0.0648 \AA$ ). The distortions necessarily lead to a range of bond angles significantly differing form the ideal tetrahedral angle $\left(94.05(3)\right.$ to $\left.129.57(4)^{\circ}\right)$. The $\mathrm{Zn}-\mathrm{N}$ and $\mathrm{Zn}-\mathrm{O}$ bond lengths in $\mathbf{3}$ agree very well with values previously observed for the only structurally characterized dmapcoordinated $\mathrm{Zn}$ ketiminate complex dmap-Zn(Et)L, which crystallized with two independant molecules in the asymmetric unit and showed $\mathrm{Zn}-\mathrm{N}_{\mathrm{DMAP}}$ bond lengths of 2.123(3) and 2.117(3) $\AA$, respectively. ${ }^{[11]}$ A CSD search for any type of $\mathrm{Zn}$ (dmap) complexes ( 46 hits, 68 bonds) revealed a mean bond length of 2.18(6) $\AA$ (range 1.986 to $2.177 \AA$ ). The $\mathrm{Zn}-\mathrm{O}$ and $\mathrm{Zn}-\mathrm{N}$ bond distances in $\mathbf{3}$ also agree very well with corresponding values observed for homo- and heteroleptic tridentate ketoiminate zinc complexes. ${ }^{[22 a, 30]}$

5 crystallizes in the orthorhombic space group Pbcn (Fig. 4). The molecule occupies special position $4 c$ and consequently shows two-fold rotational symmetry. The zinc atom is coordinated by two $\mathrm{N}, \mathrm{O}$-chelating MeNacac ligands, resulting in a tetrahedral environment at the zinc atom, which is distorted along the -4 axis since the endocyclic $\mathrm{O}-\mathrm{Zn}-\mathrm{N}$ bond angles (see Table 1) are 
restrained by the bite angle of the ligand. The six-membered ring is flat (r.m.s. deviation from best plane $0.0604 \AA$ ) and approximately perpendicular to its symmetry equivalent (88.54(3) ${ }^{\circ}$ angle between best planes). The $\mathrm{Zn}-\mathrm{N}$ and $\mathrm{Zn}-\mathrm{O}$ bond lengths again match well those observed for $\mathbf{1}$ to $\mathbf{3}$ as well as with the mean values obtained from the CSD.

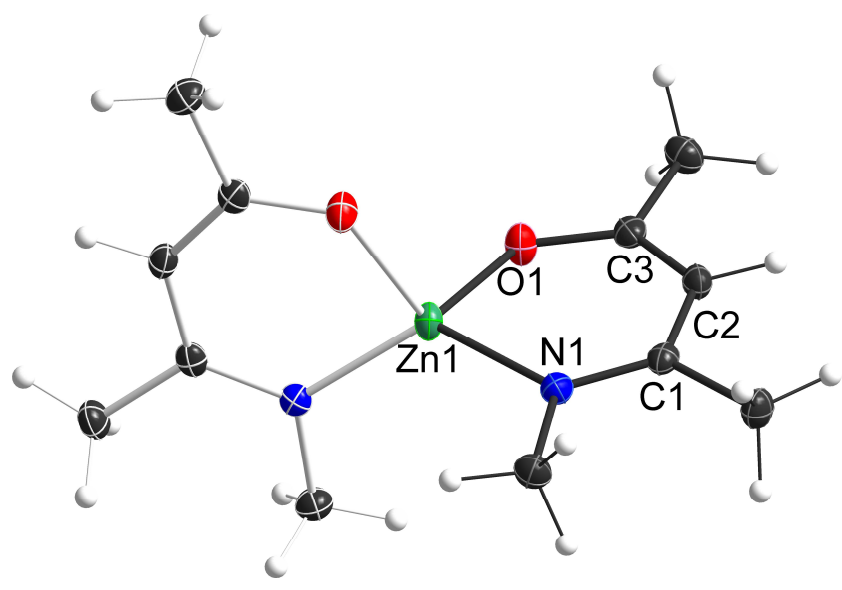

Figure 4. Solid state structure of $\mathbf{5}$, thermal ellipsoids are shown at $50 \%$ probability levels. Symmetry generated part displayed in pale colors.

Polymerization studies. $\mathbf{1}$ - $\mathbf{5}$ were tested in ROP of rac-lactide (Table 2). Kinetic experiments were performed in $\mathrm{CD}_{2} \mathrm{Cl}_{2}$ or $\mathrm{CDCl}_{3}$ at ambient temperature. 1 shows a rather slow activity in ROP of lactide compared to other catalysts containing $\beta$-diketiminate ligands. After $24 \mathrm{~h}$ only $13 \%$ were converted into the polymer, whereas a polymerization of $90 \%$ needs seven days ( $\mathrm{SI})$. In contrast, the homoleptic zinc catalyst $\mathbf{5}$ is slightly faster by converting $13 \%$ within $10 \mathrm{~h}$, but the TOFs of both catalysts (1 (1), $3(5))$ are rather disappointing. MALDI-TOF measurements show that the N,O-chelating MeNacac ligand of the homoleptic complex is able to open the lactide (Fig. S26) as was previously reported. ${ }^{[31]}$ The introduction of sterically more demanding 2,6dimethylphenol ligand in $\mathbf{2}$ results in a significant activity increase, and 2 was found to convert $80 \%$ of rac-lactide into PLA within 66 minutes with $k_{p}=1.167 \times 10^{-4} \mathrm{~L} \mathrm{~s}^{-1} \mathrm{mmol}^{-1}$. Careful analysis of the MALDI-TOF spectra of the polymers obtained with catalysts 2 and 3 suggest that the polymerization reactions proceed through the well-known coordination insertion mechanistic (CIM) pathway. The initial step in the CIM pathway is the coordination of LA to the metal center through the carbonyl oxygen atom followed by insertion of the nucleophilic substituent of the metal complex to the activated carbonyl carbon atom of LA through simple nucleophilic attack followed by rearrangement and formation of an alkoxy intermediate. This alkoxy intermediate is the authentic, active species in the ROP and the chain propagation step proceeds via repeatedly coordination of LA to the metal center followed by insertion of alkoxy group by breaking the $\mathrm{M}-\mathrm{O}$ bond. The above assumption also reflects the ROP results as summarized in table 2 . The polymerization results reveal that catalyst 2 shows a higher reactivity than catalyst 1 , which is caused by the stronger nucleophilic nature of the 2,6dimethylphenoxide ligand in $\mathbf{2}$ compared to the ethyl group in $\mathbf{1}$. The less nucleophilic Et group hampers the formation of the active alkoxy intermediate species, resulting in a high molecular weight
$\left(M_{\mathrm{n}}\right)$ of $127.000 \mathrm{~g} / \mathrm{mol}$. Catalyst 2 is also more active compared to catalyst 3, also resulting from the stronger nucleophilic nature of the dimethylphenoxide ligand compared to the dimethylamino pyridine base. Therefore, $\mathbf{2}$ again initiates the formation of the alkoxy intermediate much faster than 3 , resulting in a faster propagation of the polymer chain. The lack of reactivity in case of catalyst $\mathbf{5}$ in the ROP of lactide results from the poor nucleoplilicity of the N,O-chelating ketoiminate ligands.

The analysis of the polymerization results (table 2) also showed that a moderate correlation between observed molecular weight $\left(M_{n}\right)$ and theoretical molecular weight exist for catalyst $\mathbf{2}$ and $\mathbf{3}$, whereas the observed molecular weight obtained with catalyst 1 $\left(M_{\mathrm{n}}=127.000 \mathrm{~g} / \mathrm{mol}\right)$ was found to be much higher than the theoretical molecular weight $\left(M_{n, \text { theo: }} 28.800 \mathrm{~g} / \mathrm{mol}\right.$ for $100 \%$ conversion). This finding proves that a smaller number of active alkoxy intermediate species are produced during the polymerization reaction with catalyst 1 , hence resulting in an elongated reaction time for achieving high conversion as well as in the growth of significantly longer polymer chains. This finding clearly originates from the presence of the less nucleophilic Et group, which is a rather poor initiator in ROP of cyclic ethers. However, compared to the dinuclear zinc catalyst from Williams et al., which represents the fastest catalyst so far, complex $\mathbf{2}$ is 250 times slower. ${ }^{[10 a]}$

Table 2. Ring-opening polymerization mediated by $\mathbf{1}-\mathbf{3}$ and 5 . $^{\text {[a] }}$

\begin{tabular}{|c|c|c|c|c|c|c|c|}
\hline cat. $^{[a]}$ & $\begin{array}{l}\text { Time } \\
\text { [min] }\end{array}$ & $\begin{array}{l}\text { conv. } \\
{[\%]^{[c]}}\end{array}$ & $\begin{array}{l}\text { TOF } \\
{\left[\mathrm{h}^{-1}\right]}\end{array}$ & $\begin{array}{l}M_{n} \quad[\mathrm{~g} \\
\left.\mathrm{mol}^{-1}\right]^{[\mathrm{c}]}\end{array}$ & $P D^{[\mathrm{d}]}$ & $\begin{array}{l}k_{\text {app }} \\
10^{-5} \mathrm{~s}^{-1}\end{array}$ & $\begin{array}{l}k_{p}\left[\mathrm{Ls}^{-1}\right. \\
\left.\mathrm{mmol}^{-1}\right]\end{array}$ \\
\hline $1^{[a]}$ & $\begin{array}{l}7 \\
\text { days }\end{array}$ & 90 & 1 & 127000 & 2.0 & 0.028 & $\begin{array}{l}3.922 \times \\
10^{-8}\end{array}$ \\
\hline $2^{[\mathrm{b}]}$ & 66 & 80 & 73 & 19300 & 1.8 & 67.5 & $\begin{array}{l}1.167 \times \\
10^{-4}\end{array}$ \\
\hline [l] & 114 & 88 & 46 & 15000 & 1.8 & 30.5 & $\begin{array}{l}0.523 \times \\
10^{-4}\end{array}$ \\
\hline $5^{[a]}$ & 600 & 13 & 3 & 16300 & 1.8 & 0.163 & $\begin{array}{l}2.283 x \\
10^{-7}\end{array}$ \\
\hline
\end{tabular}

[a] [LA] / [cat] 200:1, in $0.7 \mathrm{~mL} \mathrm{CD} \mathrm{Cl}_{2}$ at RT, subl. rac-LA; [b] [LA] / [cat] 100:1, in $0.6 \mathrm{~mL} \mathrm{CDCl} 3$ at RT, subl. rac-LA; [c] determined by ${ }^{1} \mathrm{H}-\mathrm{NMR}$; [d] $P D=M_{w} / M_{n}$ as determined by GPC (in THF), $M_{n, \text { theo: }} 28800 \mathrm{~g} \mathrm{~mol}^{-1}$ for $100 \%$ conversion ([LA]/[cat] 200:1) and $14400 \mathrm{~g} \mathrm{~mol}^{-1}$ for $100 \%$ conversion (([LA]/[cat] 100:1)

Since we recently observed a beneficial influence of additional Lewis bases such as dmap on the catalytic activity of ketoiminate zinc catalyst, ${ }^{[11]}$ we also investigated the activity of the dmapcoordinated complexes 3 and 4 . Complex 3 converts $88 \%$ of raclactide into PLA within 114 minutes resulting in a $k_{p}$ value of $0.523 \times 10^{-4} \mathrm{~L} \mathrm{~s}^{-1} \mathrm{mmol}^{-1}$. Waymouth et al. have been reported the subsiding mechanism using dmap as initiator. ${ }^{[32]}$ Sole dmap is almost inactive in ROP, hence the strong activity increase upon addition of dmap to 1 points to a cooperative beneficial effect. ${ }^{[33]}$ Comparable results were expected for the phenoxy-substituted derivatives 2 and $\mathbf{4}$, but due to the very poor solubility of 4 in common organic solvents, 4 could only be investigated in bulk polymerization reactions, and the results are therefore not directly comparable with those obtained for $\mathbf{1}-\mathbf{3}$ and $\mathbf{5}$. However, these studies proved that 4 is rather active in bulk polymerization requiring much higher temperatures, converting $93 \%$ lactide to PLA within 20 minutes (SI). 
WILEY-VCH

Figure 5 shows the lactide polymerization kinetics for $\mathbf{2}$ and $\mathbf{3}$

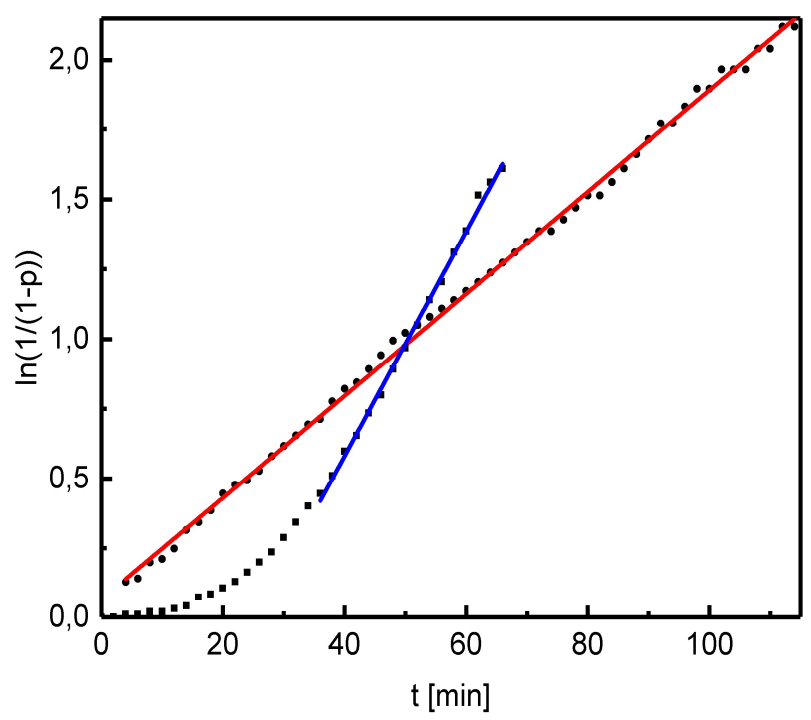

Figure 5. Plot of ring-opening polymerization (ROP) of lactide with complex 2 (blue) and 3 (red): semi-logarithmic plot of the polymerizations of rac-LA [LA]:[Init.] $=100: 1,25^{\circ} \mathrm{C}, \mathrm{CDCl}_{3}$; conversion rate determined by ${ }^{1} \mathrm{H}$ NMR spectroscopy.

While the logarithmic conversion of $\mathbf{3}$ against the time shows a linear fit, an induction phase for the polymerization using complex $\mathbf{2}$ is observed. The inducting phase is probably caused by the dissociation of the dinuclear complex. The activity and the mechanism of other dimeric species is under current investigation. Once the dissociation has occurred, both zinc centers are active to control the polymerization. The obtained molecular weights of the polymer fit well to the calculated masses under the assumption that one phenolate and one zinc atom initiate and control the polymerization. For clarifying the subsiding mechanism end-group analysis by MALDI-TOF have been performed. The results maintained that dmap in complex 3 and the phenolate in complex 2 are bound at the chain end of the polymer. In the polymerization reaction, dmap and the phenolate open the lactide ring and therefore a coordination insertion mechanism is proposed. The tested complexes $\mathbf{2}$ and $\mathbf{3}$ show characteristics of a well-defined catalyst. However, complexes 1 and $\mathbf{5}$ show a slower activity. The molecular weights for polymers obtained with 1 are much higher than the theoretical values. The broad polydispersity of the resulting polymer obtained with catalyst 1 indicates that transesterification reactions occur during the ROP.

Pulsed-gradient spin echo (PGSE) measurements were performed to investigate the structures of 1 - 3 in $\mathrm{CH}_{2} \mathrm{Cl}_{2}$ and THF solution (Table 3), respectively. In non-coordinating $\mathrm{CH}_{2} \mathrm{Cl}_{2}$, the hydrodynamic radius of $\mathbf{1}$ is smaller than that of $\mathbf{3}$, which indicates that both molecules adopt monomeric structures in solution, and the larger hydrodynamic radius of $\mathbf{3}$ results from the coordination of the strong Lewis base dmap. In contrast, the hydrodynamic radii of $\mathbf{2}$ in dichloromethane and in THF are significantly larger, indicating the formation of dimeric molecules in solution as was observed in the solid state.
Table 3. PGSE measurements of 1 - 3 [a]

\begin{tabular}{llll}
\hline Solvent & $\mathbf{1}$ & $\mathbf{2}$ & $\mathbf{3}$ \\
\hline $\mathrm{CH}_{2} \mathrm{Cl}_{2}$ & 3.309 & 5.242 & 4.079 \\
$\mathrm{THF}$ & 3.692 & 5.521 & 3.762 \\
\hline
\end{tabular}

[a] Measurements were performed at $25^{\circ} \mathrm{C}$.

According to these NMR studies, the inducting phase in the ROP of lactide using complex 2 may by caused by the dissociation of dimeric 2 into the monomeric complex. The monomeric complex then raidly polymerizes lactide due to the strong nucleophilic nature of the 2,6-dimethylphenoxide ligand, which readily attacks the electrophilic carbon center of the coordinated lactide. In contrast, $\mathbf{1}$ and $\mathbf{3}$, which are expected to be monomeric in solution under ROP conditions, are less active in lactide polymerization due to the less nucleophilic nature of the Et substituent compared to the 2,6-dimethylphenoxide ligand in 2.

\section{Conclusions}

One homoleptic and four heteroleptic zinc ketoiminate complexes were synthesized and four of them were characterized by single crystal X-ray analysis. The complexes were investigated for the ROP of lactide and the heteroleptic complexes $\mathbf{2}$ and $\mathbf{3}$ containing an additional phenoxide or Lewis base substituent at the $\mathrm{Zn}$ atom turned out to be much more active catalysts compared to 1 and $\mathbf{5}$, respectively. Moreover, the beneficial effect of the addition of the external Lewis base dmap on the catalytic activity was revealed The complexes convince by their simple synthesis and their high catalytic performance.

\section{Experimental Section}

Reactions were performed in purified $\mathrm{Ar}$ atmosphere using standard Schlenk and glovebox techniques. Solvents were carefully dried over and degassed prior to use. Deuterated solvents were stored over activated molecular sieves $(4 \AA)$. Karl Fischer titration of the dry solvents showed values below $2 \mathrm{ppm}$. The ketoimine $\mathrm{LH}$ was prepared by literature method. ${ }^{[34]}$ 2,6-dimethylphenol and dmap (Acros) were sublimed before use.

MALDI-TOF mass spectrometry: The end group analysis was performed by MALDI-TOF on a Bruker ultrafleXtreme equipped with a $337 \mathrm{~nm}$ smartbeam laser in the reflective mode. THF solutions of trans-2-[3-(4-tertbutylphenyl)-2-methyl-2-propenylidene]malono-nitrile (DCTB) $(5 \mu \mathrm{L}$ of a $20 \mathrm{mg} / \mathrm{mL}$ solution), sodium trifluoroacetate $(0.1 \mu \mathrm{L}$ of a $10 \mathrm{mg} / \mathrm{mL}$ solution), and analyte ( $5 \mu \mathrm{L}$ of a $10 \mathrm{mg} / \mathrm{mL})$ were mixed and a droplet thereof applied on the sample target. Protein 1 calibration standard is the name of the protein mixture used for calibration. For spectra 4000 laser shots with $24 \%$ laser power were collected. The laser repetition rate was $1000 \mathrm{~Hz}$. The homopolymer analysis was performed using Polymerix software (Sierra Analytics)

${ }^{1} \mathrm{H}(300 \mathrm{MHz})$ and ${ }^{13} \mathrm{C}\left\{{ }^{1} \mathrm{H}\right\}(75.5 \mathrm{MHz}) \mathrm{NMR}(\delta$ in ppm) spectra were recorded using a Bruker Avance 300 or a Bruker Avance III $\left({ }^{1} \mathrm{H}, 400 \mathrm{MHz}\right)$ spectrometer and the spectra were referenced to internal THF-d $8\left({ }^{1} \mathrm{H}: \delta=\right.$ 1.72, 3.58; $\left.{ }^{13} \mathrm{C}: 67.21,25.31\right), \mathrm{CDCl}_{3}\left({ }^{1} \mathrm{H}: \delta=7.26\right)$ and $\mathrm{CD}_{2} \mathrm{Cl}_{2}\left({ }^{1} \mathrm{H}: \delta=\right.$ $\left.5.32 ;{ }^{13} \mathrm{C}: 53.84\right)$. Microanalyses were performed at the elemental analysis laboratory of the University of Duisburg-Essen. IR Spectra were recorded on an ALPHA-T FTIR spectrometer equipped with a single reflection ATR 
sampling module. The spectrometer was placed in a glovebox to avoid hydrolysis and oxidation reactions.

Gel Permeation Chromatography (GPC): The average molecular weights and the weight of the obtained polylactide samples were determined by gel permeation chromatography (GPC) in THF as mobile phase at a flow rate of $1 \mathrm{~mL} / \mathrm{min}$. The utilized GPCmax VE-2001 from Viscotek is a combination of an HPLC pump, two Malvern Viscotek T columns (porous styrene divinylbenzene copolymer) with a maximum pore size of 500 and $5000 \AA$ and a refractive index detector (VE-3580) and a viscometer (Viscotek 270 Dual Detector). Universal calibration (polystyrol as standard) was applied to evaluate the chromatographic results.

Polymerizations experiments in solution were performed at room temperature with sublimed rac-lactide and the corresponding catalyst in a molar ratio of either 200:1 (144.13 mg, $1 \mathrm{mmol}$ rac-lactide, $0.005 \mathrm{mmol} 1$ \& 5) in $0.7 \mathrm{~mL} \mathrm{CD} \mathrm{Cl}_{2}(\mathbf{1}, \mathbf{5})$ or in a molar ratio of $100: 1(50 \mathrm{mg}, 0.347 \mathrm{mmol}$ rac-lactide, $0.0035 \mathrm{mmol} 2 \& 3)$ in $0.6 \mathrm{~mL} \mathrm{CDCl}_{3}(2,3)$, respectively. The bulk polymerization experiment with 4 was performed at $140{ }^{\circ} \mathrm{C}$ in a molar ratio of either 200:1 with the same amounts as in solution. The polymer was dried in vacuum and the conversion rate was determined from the ${ }^{1} \mathrm{H}$ NMR spectra by integration of methyl protons of the monomer $(\delta=1.53$ $\mathrm{ppm})$ versus the methyl protons of the polymer $(\delta=1.47 \mathrm{ppm})$.

Synthesis of 1: A solution of LH (282.9 mg, $2.5 \mathrm{mmol})$ in $10 \mathrm{~mL}$ of THF was added to a solution of $\mathrm{ZnEt}_{2}(2.5 \mathrm{~mL}, 1 \mathrm{M} / \mathrm{L}$ in hexanes $)$ in $10 \mathrm{~mL}$ of $\mathrm{THF}$ at $-60{ }^{\circ} \mathrm{C}$. After stirring for $12 \mathrm{~h}$, the solvent was removed in vacuum, yielding a colorless crystalline solid, that was recrystallized from a solution in $5 \mathrm{~mL}$ of THF at $-30{ }^{\circ} \mathrm{C}$. Yield: $412 \mathrm{mg}(80 \%)$. M.p.: $137^{\circ} \mathrm{C}$. Anal. calc. for $\mathrm{C}_{8} \mathrm{H}_{15} \mathrm{NOZn:} \mathrm{C} 46.51, \mathrm{H} 7.32$, N 6.78; found: C 46.30, H 7.29; N $6.92 \%$. ${ }^{1} \mathrm{H}$ NMR (THF-d8, $25^{\circ} \mathrm{C}$ ): $\delta=0.11\left(\mathrm{q},{ }^{3} \mathrm{~J}_{\mathrm{HH}}=8.1 \mathrm{~Hz}, 2 \mathrm{H}, \mathrm{ZnCH}_{2} \mathrm{CH}_{3}\right), 1.21$ $\left(\mathrm{t},{ }^{3} \mathrm{~J}_{\mathrm{HH}}=8.1 \mathrm{~Hz}, 3 \mathrm{H} \mathrm{ZnCH} \mathrm{CH}_{3}\right), 1.80\left(\mathrm{~s}, 3 \mathrm{H}, \mathrm{CCH}_{3}\right), 1.87\left(\mathrm{~s}, 3 \mathrm{H}, \mathrm{CCH}_{3}\right)$, 3.07 (s, 3H, NCH$\left.H_{3}\right), 4.76(\mathrm{~s}, 1 \mathrm{H}, \mathrm{CH}) .{ }^{13} \mathrm{C} \mathrm{NMR}\left(\mathrm{THF}_{-} \mathrm{d}_{8}, 25^{\circ} \mathrm{C}\right): \delta=6.40$ $\left(\mathrm{ZnCH}_{2} \mathrm{CH}_{3}\right), 10.65\left(\mathrm{ZnCH}_{2} \mathrm{CH}_{3}\right), 18.03\left(\mathrm{CCH}_{3}\right), 24.63\left(\mathrm{CCH}_{3}\right), 35.51$ $\left(\mathrm{NCH}_{3}\right), 99.93(\mathrm{CH}), 170.03(\mathrm{CN}), 179.54(\mathrm{CO}) . \mathrm{IR}: \mathrm{v} 2849,1612,1531$ $1384,1262,1210,995,926,855,781,679,641,606,572,503,434$.

Synthesis of 2: A solution of 2,6-Dimethylphenol (179.12 $\mathrm{mg}, 1.47 \mathrm{mmol}$ ) in $10 \mathrm{~mL}$ of $\mathrm{THF}$ was dropwise added to a cooled $\left(-90^{\circ} \mathrm{C}\right)$ solution of 1 (300 $\mathrm{mg}, 1.47 \mathrm{mmol}$ ) in $10 \mathrm{~mL}$ of THF. The solution was slowly warmed to ambient temperature and stirred for additional $2 \mathrm{~h}$. The solvent was evaporated in vacuum and the resulting crystalline solid was re-crystallized from a solution in $5 \mathrm{~mL}$ of THF at $-30{ }^{\circ} \mathrm{C}$. Yield: $370 \mathrm{mg}(84 \%)$ of 3 as powder. M.p.: $178{ }^{\circ} \mathrm{C}$. Anal. calc. for $\mathrm{C}_{14} \mathrm{H}_{19} \mathrm{NO}_{2} \mathrm{Zn}$ : C 56.30, H 6.41, N 4.69; found: $\mathrm{C} 55.98, \mathrm{H} 6.61$; $\mathrm{N} 4.62 \%$. ${ }^{1} \mathrm{H}$ NMR $\left(\mathrm{CD}_{2} \mathrm{Cl}_{2}, 25^{\circ} \mathrm{C}\right): \delta=1.85$ (s, 3H, $\left.\mathrm{CCH}_{3}\right), 1.86$ (s, 3H, CCH $\mathrm{CH}_{3}, 2.38\left(\mathrm{~s}, 6 \mathrm{H}, \mathrm{o}-\mathrm{CH}_{3}\right), 3.23\left(\mathrm{~s}, 3 \mathrm{H}, \mathrm{NCH}_{3}\right)$, $4.79(\mathrm{~s}, 1 \mathrm{H}, \mathrm{CH}), 6.65\left(\mathrm{t},{ }^{3} \mathrm{~J}_{\mathrm{HH}}=7.4 \mathrm{~Hz}, 1 \mathrm{H}, p-\mathrm{CH}\right), 6.92\left(\mathrm{~d},{ }^{3} \mathrm{~J}_{\mathrm{HH}}=7.4 \mathrm{~Hz}\right.$, $2 \mathrm{H}, m-\mathrm{CH}) .{ }^{13} \mathrm{C}$ NMR $\left(\mathrm{CD}_{2} \mathrm{Cl}_{2}, 25^{\circ} \mathrm{C}\right): \delta=17.42\left(\mathrm{o}-\mathrm{CCH}_{3}\right), 21.96\left(\mathrm{CCH}_{3}\right)$, $27.85\left(\mathrm{CCH}_{3}\right), 39.08\left(\mathrm{NCH}_{3}\right), 97.41(\mathrm{CH}), 119.67(p-\mathrm{CH}), 128.86(m-\mathrm{CH})$, $176.69(\mathrm{CN}), 183.98$ (CO). IR (neat): v 2961, 1591, 1509, 1461, 1417, 1392, 1381, 1369, 1262, 1229, 1209, 1158, 1092, 1015, 998, 936, 917, $860,837,799,770,751,687,643,599,579,522,488,458$.

Synthesis of 3: DMAP (179.1 mg, $1.47 \mathrm{mmol}$ ) was added to a solution of 1 (300 mg, $1.47 \mathrm{mmol}$ ) in $15 \mathrm{~mL}$ of THF and stirred at ambient temperature for $1 \mathrm{~h}$. The solvent was then removed in vacuum and the resulting crystalline solid was re-crystallized from a solution in $5 \mathrm{~mL}$ of toluene at $30{ }^{\circ} \mathrm{C}$. Yield $455 \mathrm{mg}(95 \%)$. M.p.: $101{ }^{\circ} \mathrm{C}$. Anal. calc. for $\mathrm{C}_{15} \mathrm{H}_{25} \mathrm{~N}_{3} \mathrm{OZn}$ : C 54.80, H 7.67, N 12.78, found: C 53.40, H 7.73; N 13.10\%. ${ }^{1} \mathrm{H}$ NMR $\left(\mathrm{CD}_{2} \mathrm{Cl}_{2}, 25^{\circ} \mathrm{C}\right): \delta=0.09\left(\mathrm{q},{ }^{3} \mathrm{~J}_{\mathrm{HH}}=8.1 \mathrm{~Hz}, 2 \mathrm{H} \mathrm{ZnCH} \mathrm{CH}_{3}\right), 1.23\left(\mathrm{t},{ }^{3} \mathrm{~J}_{\mathrm{HH}}=\right.$ $\left.8.1 \mathrm{~Hz}, 3 \mathrm{H}, \mathrm{ZnCH}_{2} \mathrm{CH}_{3}\right), 1.84$ (s, 3H, $\left.\mathrm{CCH}_{3}\right), 1.85$ (s, 3H, CCH $), 2.98$ (s, $\left.3 \mathrm{H}, \mathrm{NCH}_{3}\right), 3.01\left(\mathrm{~s}, 6 \mathrm{H}, \mathrm{N}\left(\mathrm{CH}_{3}\right)_{2}\right), 4.71(\mathrm{~s}, 1 \mathrm{H}, \mathrm{CH}), 6.52\left(\mathrm{~d},{ }^{3} \mathrm{~J}_{\mathrm{HH}}=5.3 \mathrm{~Hz}\right.$, $2 \mathrm{H}, m$-CHDMAP), 7.96 (d, ${ }^{3} \mathrm{~J}_{\mathrm{HH}}=5.3 \mathrm{~Hz}, 2 \mathrm{H}, o-\mathrm{CH}$ DMAP). ${ }^{13} \mathrm{C} \mathrm{NMR}\left(\mathrm{CD}_{2} \mathrm{Cl}_{2}\right.$, $\left.25^{\circ} \mathrm{C}\right): \delta=-3.78\left(\mathrm{ZnCH}_{2} \mathrm{CH}_{3}\right), 13.97\left(\mathrm{ZnCH}_{2} \mathrm{CH}_{3}\right), 21.13\left(\mathrm{CCH}_{3}\right), 27.85$ $\left(\mathrm{CCH}_{3}\right), 38.26\left(\mathrm{NCH}_{3}\right), 39.50\left(\mathrm{~N}\left(\mathrm{CH}_{3}\right)_{2}\right), 96.21(\mathrm{CH}), 107.13\left(\mathrm{~m}-\mathrm{CH}_{\text {DMAP }}\right)$, 148.70 (o-CH $\left.\mathrm{CHMP}_{\text {DMA }}\right), 155.58\left(\mathrm{CN}\left(\mathrm{CH}_{3}\right)_{2}\right), 171.88(\mathrm{CN}), 181.25(\mathrm{CO}) . \mathrm{IR}$ (neat): v 2843, 1600, 1504, 1419, 1389, 1269, 1223, 1068, 110, 937, 800, $754,576,523,490,430$.
Synthesis of 4: A solution of DMAP $(34.3 \mathrm{mg}, 0.28 \mathrm{mmol})$ in $5 \mathrm{~mL}$ of THF was added to a solution of $2(83.8 \mathrm{mg}, 0.28 \mathrm{mmol})$ in $5 \mathrm{~mL}$ of THF and stirred at ambient temperature. The resulting white precipitate was isolated by filtration. Yield $101 \mathrm{mg}(91 \%) .{ }^{1} \mathrm{H} \mathrm{NMR}\left(\mathrm{CD}_{2} \mathrm{Cl}_{2}, 25^{\circ} \mathrm{C}\right): \delta=1.89(\mathrm{~s}, 3 \mathrm{H}$, $\left.\mathrm{CCH}_{3}\right), 1.91$ (s, 3H, $\left.\mathrm{CCH}_{3}\right), 2.14$ (s, 6H, o- $\left.\mathrm{CH}_{3}\right), 2.99\left(\mathrm{~s}, 6 \mathrm{H}, \mathrm{N}\left(\mathrm{CH}_{3}\right)_{2}\right), 3.04$ $\left(\mathrm{s}, 3 \mathrm{H}, \mathrm{NCH}_{3}\right), 4.82(\mathrm{~s}, 1 \mathrm{H}, \mathrm{CH}), 4.71(\mathrm{~s}, 1 \mathrm{H}, \mathrm{CH}), 6.34\left(\mathrm{t}, 3^{3} \mathrm{~J}_{\mathrm{HH}}=6.7 \mathrm{~Hz}\right.$, $1 \mathrm{H}, p-\mathrm{CH}), 6.55\left(\mathrm{~d},{ }^{3} \mathrm{~J}_{\mathrm{HH}}=5.3 \mathrm{~Hz}, 2 \mathrm{H}, m-\mathrm{CH}\right.$ DMAP), $6.82\left(\mathrm{~d},{ }^{3} \mathrm{~J}_{\mathrm{HH}}=7.1 \mathrm{~Hz}\right.$, $2 \mathrm{H}, m-\mathrm{CH}), 8.07\left(\mathrm{~d},{ }^{3} \mathrm{~J}_{\mathrm{HH}}=5.2 \mathrm{~Hz}, 2 \mathrm{H}, o-\mathrm{CH}\right.$ DMAP). ${ }^{13} \mathrm{C} \mathrm{NMR}\left(\mathrm{CD}_{2} \mathrm{Cl}_{2}\right.$, $\left.25^{\circ} \mathrm{C}\right): \delta=17.78\left(\mathrm{o}-\mathrm{CCH}_{3}\right), 21.36\left(\mathrm{CCH}_{3}\right), 27.55\left(\mathrm{CCH}_{3}\right), 38.07\left(\mathrm{NCH}_{3}\right)$, $39.43\left(\mathrm{~N}\left(\mathrm{CH}_{3}\right)_{2}\right), 96.75(\mathrm{CH}), 107.13\left(m-C \mathrm{H}_{\text {DMAP }}\right), 114.05(p-\mathrm{CH}), 126,87$ $(m-\mathrm{CH}), 128.03(\mathrm{o}-\mathrm{CH}), 148.69$ (o-CHDMAP $), 155.72\left(\mathrm{CN}\left(\mathrm{CH}_{3}\right)_{2}\right), 164.43$ (ipso-C), $174.93(\mathrm{CN}), 182.80$ (CO). M.p.: $198{ }^{\circ} \mathrm{C}$ (dec.). Anal. calc. for $\mathrm{C}_{15} \mathrm{H}_{25} \mathrm{~N}_{3} \mathrm{OZn}$ : C 59.93, H 6.95, N 9.98, found: C 59.20, H 7.09, N 10.40\%. IR (neat): v 2824, 1507, 1458, 1326, 1016, 757, 523, 435.

Synthesis of 5: A solution of LH $(265.8,5 \mathrm{mmol})$ in THF was added to a solution of $\mathrm{ZnEt}_{2}(2.5 \mathrm{~mL}, 1 \mathrm{M} / \mathrm{L}$ in hexanes) in THF at ambient temperature and the resulting solution was stirred for 30 minutes. The solvent was removed in vacuum, yielding a colorless crystalline solid, which was recrystallized from THF at $-30^{\circ} \mathrm{C}$. Yield: $612 \mathrm{mg}(85 \%)$. M.p.: $162{ }^{\circ} \mathrm{C}$. Anal. calc. for $\mathrm{C}_{12} \mathrm{H}_{20} \mathrm{~N}_{2} \mathrm{O}_{2} \mathrm{Zn}$ : C 49.75, H 6.96, N 9.67; found: C 49.50, H 7.07; N 9.80\%. ${ }^{1} \mathrm{H}$ NMR (THF-d $\left.8,25^{\circ} \mathrm{C}\right): \delta=1.82\left(\mathrm{~s}, 3 \mathrm{H}, \mathrm{CCH}_{3}\right), 1.91(\mathrm{~s}, 3 \mathrm{H}$, $\left.\mathrm{CCH}_{3}\right), 2.96\left(\mathrm{~s}, 3 \mathrm{H}, \mathrm{NCH}_{3}\right), 4.77(\mathrm{~s}, 1 \mathrm{H}, \mathrm{CH}) .{ }^{13} \mathrm{C} \mathrm{NMR}\left(\mathrm{THF}-\mathrm{d}_{8}, 25^{\circ} \mathrm{C}\right): \delta$ $=18.11\left(\mathrm{CCH}_{3}\right), 24.64\left(\mathrm{CCH}_{3}\right), 34.90\left(\mathrm{NCH}_{3}\right), 93.89(\mathrm{CH}), 171.98(\mathrm{CN})$, 180.58 (CO). IR (neat): v 1589, 1501, 1422, 1386, 1270, 1224, 1089, 995, $938,757,681,453$.

Single crystal X-ray analyses. The crystals were mounted on nylon loops in inert oil. Data were collected on a Bruker AXS D8 Kappa diffractometer

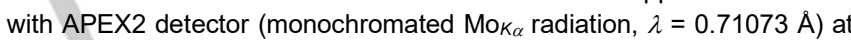
100(2) K. The structures were solved by Direct Methods (SHELXS-97) ${ }^{[35]}$ and refined anisotropically by full-matrix least-squares on $F^{2}$ (SHELXL2014).[36] Absorption corrections were performed semi-empirically from equivalent reflections on basis of multi-scans (Bruker AXS APEX2). Hydrogen atoms were refined using a riding model or rigid methyl groups. In 2 the THF is disordered over three different positions with a total occupancy of about 0.75 . SADI restraints were employed for all 1,2 and 1,3 distances. RIGU, DELU, and SIMU restraints were applied to the ADP of all solvent atoms and an additional ISOR restraint to the ADP of the solvents' $O$ atoms. Removing the solvent contribution to the electron density with SQUEEZE[37] slightly improved the R-values, however since the solvent positions were recognizable and (with vast use of restraints) refinable we chose to discard this model.

The crystallographic data of $\mathbf{1}$ - $\mathbf{3}$ and $\mathbf{5}$ (excluding structure factors) have been deposited with the Cambridge Crystallographic Data Centre as supplementary publication nos. CCDC-1569530 (1), CCDC-1569531 (2) CCDC-1569532 (3) and CCDC-1569533 (5). Copies of the data can be obtained free of charge on application to CCDC, 12 Union Road, Cambridge, CB21EZ (fax: (+44) 1223/336033; e-mail: deposit@ccdc.camak.uk).

Supporting Information. A CIF file giving X-ray crystallographic data of 1 - 3 and $5 .{ }^{1} \mathrm{H},{ }^{13} \mathrm{C}$ NMR and IR spectra of $\mathbf{1}-\mathbf{5}$ as well as crystallographic details of $\mathbf{1}-\mathbf{3}$ and $\mathbf{5}$ are given. This material is available free of charge via the Internet at http://pubs.acs.org.

\section{Acknowledgements}

Financial support by the University of Duisburg-Essen (S.S.) as well as Evonik Industries (P.S. doctoral fellowship) is acknowledged. P.M.S. thanks the Hanns-Seidel-Foundation (fellowship) for funding (Bundesministerium für Bildung und Forschung, BMBF). This study was performed in part by the Center for Chemical Polymer Technology (CPT), which is 
supported by the European Union and the Federal state of North Rhine-Westphalia (grant no. EFRE 300088302). S.H.-P. and A.P. thank the Deutsche Forschungsgemeinschaft for funding in the framework of the SFB985.

Keywords: zinc $\cdot$ polylactide $\cdot$ polymerization $\cdot X R D \cdot$ ketoiminate $\cdot$ catalysis

[1] S. Mecking, Angew. Chem. 2004, 116, 1096-1104; Angew. Chem. Int. Ed. 2004, 43, 1078-1085

[2] a) Y. Tsa, C. Lin, C. Lin, B. Ko, J Polym Sci Part A: Polym Chem 2009 47, 4927-4936; b) K. Rezwan, Q. Z. Chen, J. J. Blaker, A. R. Boccaccini, Biomaterials 2006, 27, 3413-3431.

[3] a) K. Masutani, Y. Kimura, PLA Synthesis. From the Monomer to the Polymer, Chapter 1, in Polylactic acid, Science and Technology: Processing, Properties, Additives and Applications, 2014, 1-36; b) A. Stjerndahl, A. Finne-Wistrand, A.-C. Albertsson, C. M. Bäckesjö, U. Lindgren, J. Biomed. Mater. Res. 2008, 87A, 1086-1091. c) A. Södergård M Stolt, Industrial Production of High Molecular Weigth Poly(Lactid Acid), Chapter 3 In Poly(Lactic Acid): Synthesis, Structures, Properties, Processing, and Applications, Eds. R. Auras, L.-T. Lim, S. E. M. Selke, H. Tsuji, John Wiley \& Sons, Inc., Hoboken, New Jersey, 2010; d) S. C. Agwuncha, E. R. Sadiku, I. D. Ibrahim, B. A. Aderibigbe, B. A. Aderibigbe S. J. Owonubi, O. Agboola, A. Babul Reddy, M. Bandla, K. Varaprasad, B. L. Bayode, S. S. Ray, Poly (Lactic Acid) Biopolymer Composites and Nanocomposites for Biomedicals and Biopackaging Applications, Chapter 6 In Handbook of Composites from Renewable Materials, Vol. 8, Nanocomposites: Advanced Applications, Eds. V. K. Thakur, M. K. Thakur, M. R. Kessler, John Wiley \& Sons, Inc., Hoboken, New Jersey, 2017.

[4] P. M. Schäfer, M. Fuchs, A. Ohligschläger, R. Rittinghaus, P. McKeown, E. Akin, M. Schmidt, A. Hoffmann, M. A. Liauw, M. D. Jones, S. HerresPawlis, ChemSusChem 2017, 10, 3547.

[5] a) M. H. Chisholm, J. C. Gallucci, K. Phomphrai, Inorg. Chem. 2004, 43, 6717-6725; b) M. H. Chisholm, J. C. Gallucci, K. Phomphrai, Chem. Commun. 2003, 48-49; c) M. J. Walton, S. J. Lancaster, C. Redshaw Chem CatChem 2014, 6, 1892-1898.

[6] a) A. Pilone, N. De Maio, K. Press. V. Venditto, D. Pappalardo, M. Mazzeo, C. Pellechia. M. Kol, M. Lamberti, Dalton Trans, 2015, 44, 2157 2165; b) A. B. Kremer, R. J. Andrews, M. J. Milner, X. R. Zhang, T. Ebrahimi, B. O. Patrick. P. L. Diaconescu, P. Mehrkovandi, Inorg. Chem 2017, 56, 1375-1385; c) C. Bonné, A. Pahwa, C. Picard, M. Visseaux, Inorg. Chim. Acta 2017, 455, 521-527.

[7] a) U. Herber, K. Hegner, D. Wolters, R. Siris, K. Wrobel, A. Hoffmann, C. Lochenie, B. Weber, D. Kuckling, S. Herres-Pawlis, Eur. J. Inorg. Chem. 2017, 1341-1354; b) R. Lapenta, A. Buonerba, A. De Nisi, M. Monari, A. Grassi, S. Milione, C. Capacchione, Inorg. Chem. 2017, 56, 3447-3458; C) D. Mandal, D. Chakraborty, V. Ramkumar, D. Chand, RSC Adv. 2016, 6, 21706-21718; d) B. Jia, X. Wei, H. Tong, M. Zhou, D. Liu, Inorg. Chim. Acta 2012, 388, 127-134; e) D. Jedrzkiewicz, G. Adamus, M. Kwiecien, L. John, J. Ejfler, Inorg. Chem. 2017, 56, 1349-1365. f) M. D. Jones, L. Brady, P. McKeown, A. Buchard, P. M. Schäfer, L. H. Thomas, M. F. Mahon, T. J. Woodman, J. P. Lowe, Chem. Sci. 2015, 6, 5034-5039; g) M. D. Jones, S. L. Hancock, P. McKeown, P. M. Schäfer, A. Buchard, L. H. Thomas, M. F. Mahon, J. P. Lowe, Chem. Commun. 2014, 50, 1596715970.

[8] a) Y. Duan, J. He, W. Wang, J. Zhou, Y. Huang, Y. Yang, Dalton Trans. 2016, 45, 10807-10820; b) S. Yang, K. Nie. Y. Zhang, M. Xue, Y. Yao Q. Shen, Inorg. Chem. 2014, 53, 105-115; c) A. Buchard, R. H. Platel, A. Auffrant, X. F. Le Goff, P. Le Floch, C. K. Williams, Organometallics 2010 , 29, 2892-2900.

[9] For review articles see: a) C. M. Thomas, Chem. Soc. Rev., 2010, 39, 165-173; b) J. Wu, Te-Liang Yu, C.-T. Chen, C.-C. Lin Coord. Chem. Rev. 2006, 250, 602-626; c) O. Dechy-Cabaret, B. Martin-Vaca, D. Bourissou, Chem. Rev. 2004, 104, 6147-6176; d) P. J. Dijkstra, H. Du, J. Feijen, Polym. Chem. 2011, 2, 520-527; e) P. Dubois, O. Coulembier, J. Raquez in Handbook of Ring-Opening Polymerization, Wiley-VCH, Weinheim, 2009; f) Y. Sarazin, J. Carpentier, Chem. Rev. 2015, 115, 3564-3614.

[10] a) A. Thevenon, C. Romain, M. S. Bennington, A. J. P. White, H J. Davidson, S. Brooker, C. K. Williams, Angew. Chem. 2016, 128, 88228827, Angew. Chem. Int. Ed. 2016, 55, 8680-8685; b) J. Börner, S. Herres-Pawlis, U. Flörke, K. Huber, Eur. J. Inorg. Chem. 2007, 56455651; c) A. Döring. U. Flörke, A. Hoffmann, M. D. Jones, D. Kuckling, J. Michaelis de Vasconcellos, S. Herres-Pawlis, Z. Anorg. Allg. Chem. 2015, 641, 2147-2156; d) C. Scheiper, S. Schulz, C. Wölper, D. Bläser, J. Roll, Z. Anorg. Allg. Chem. 2013, 639, 1153-1159; e) X. Pang, R. Duan, X. Li, Z. Sun, H. Zhang, X. Wang, X. Chen, Polym. Chem. 2014, 5, 6857-6864; f) S. Bian, S. Abbina. Z. Lu, E. Kolodka, G. Du, Organometallics 2014, 33, 2489-2495; g) C. Scheiper, C. Wölper, D. Bläser, J. Roll, S. Schulz, Z. Naturforsch. 2014, 69b, 1365-1374.

[11] C. Scheiper, D. Dittrich, C. Wölper, D. Bläser, J. Roll, S. Schulz, Eur. J. Inorg. Chem. 2014, 2230-2240.

[12] C. K. Williams, L. E. Breyfogle, S. K. Choi, W. Nam, V. G. Young, M. A Hillmyer, W. B. Tollman, J. Am. Chem. Soc. 2003, 125, 11350-13359.

[13] a) A. Metz, R. Plothe, B. Glowacki, A. Koszalkowski, A. Scheckenbach, A. Behringer, T. Rösener, J. Michaelis de Vasconcellos, R. Haase, U. Flörke, A. Hoffmann, S. Herres-Pawlis, Eur. J. Inorg. Chem. 2016, 4974 4987; b) A. Döring, U. Flörke, A. Hoffmann, M. D. Jones, D. Kuckling, J. Michaelis de Vasconcellos, S. Herres-Pawlis, Z. Anorg. Allg. Chem. 2015, 641, 2147-2156.

[14] M. H. Chisholm, J. C. Gallucci, H. Zhen, Inorg. Chem. 2001, 40, 50515054 .

[15] M. Horando, A. Otero, J. Fernandez-Bazea, L. F. Sanchez-Barba, A Garces, A. Lara-Sanchez, A. M. Rodriguez, Dalton Trans. 2014, 43, 17090-17100.

[16] a) H. Chen, H. Tang, C. Lin, Macromolecules 2006, 39, 3745-3752; b) I. D'Auria, M. Lamberti, M. Mazzeo, S. Milione, G. Roviello, C. Pelleccia, Chem. Eur. J. 2012, 2349-2360.

[17] a) Z. Liu, W. Gao, J. Zhang, D. Cui, Q. Wu, Y. Mu, Organometallics 2010 29, 5783-5790; b) G. Schnee, C. Fliedel, T. Avilés, S. Dagorne, Eur. J. Inorg. Chem. 2013, 3699-3709; c) C. Fliedel, V. Rosa, F. M. Alves, A. M Martins, T. Avilés, S. Dagorne, Dalton Trans. 2015, 44, 12376-12387; d) C. Fliedel, D. Vila-Viçosa, M. J. Calhorda, S. Dagorne, T. Avilés, ChemCatChem 2014, 6, 1357-1367.

[18] a) M. H. Chisholm, J. C. Gallucci, K. T. Quisenberry, Z. Zhou, Inorg Chem. 2008, 47, 2613-2624; b) A. Pilone, K. Press, J. Goldberg, M. Kol, M. Mazzeo, M. Lamberti, J. Am. Chem. Soc. 2014, 136, 2940-2943; c) T. K. Saha, V. Ramkumar, D. Chakraborty, Inorg. Chem. 2011, 50, 2720 2722.

[19] a) W. Chuang. H. Chen, W. Chen, H. Chang, M. Y. Chiang, H. Chen, S C. N. Hsu, RSC Adv. 2016, 6, 36705-36714; b) O. S. Trofymchuck, C. G Daniliuc, G. Kehr, G. Erker, R. S. Rojas, RSC Adv. 2015, 5, 21054-21065.

[20] a) B. M. Chamberlain, M. Cheng, D. R. Moore, T. M. Ovitt, E. B. Lobkovsky, G. W. Coates, J. Am. Chem. Soc. 2001, 123, 3229-3238-; b) L. R. Rieth, D. R. Moore, E. B. Lobkovsky, G. W. Coates, J. Am. Chem. Soc. 2002, 124, 15239-15248.

[21] a) E. L. Marshall, V. C. Gibson, H. S. Rzepa, J. Am. Chem. Soc. 2005, 127, 6048-6051; b) A. P. Dove, V. C. Gibson, E. L. Marshall, H. S. Rzepa A. J. P. White, D. J. Williams, J. Am. Chem. Soc. 2006, 128, 9834-9843.

[22] a) C. C. Roberts, B. R. Barnett, D. B. Green, J. M. Fritsch, Organometallics 2012, 31, 4133-4141; b) C. Di lulio, M. Middelton, G. Kociok-Köhn, M. D. Jones, A. L. Johnson, Eur. J. Inorg. Chem. 2013 1541-1554; c) N. M. Rezayee, K. A. Gerling, A. L. Rheingold. J. M. Fritsch Dalton Trans. 2013, 42, 5573-5586.

[23] T. Ebrahimi, E. Mamleeva, I. Yu, S. G. Hatzikiriakos, P. Mehrkhodavandi, Inorg. Chem. 2016, 55, 9445-9453.

[24] a) S. Schulz, T. Eisenmann, S. Schmidt, D. Bläser, U. Westphal, R. Boese, Chem. Commun. 2010, 46, 7226-7228, b) S. Schulz, T. Eisenmann, D. Schuchmann, M. Bolte, M. Kirchner, R. Boese, J. Spielmann, S. Harder, Z. Naturforsch. 2009, 64b, 1397-1400; c) S Schulz, T. Eisenmann, D. Bläser, R. Boese, Z. Anorg. Allg. Chem. 2009, 635, 995-1000; d) S. Schulz, T. Eisenmann, U. Westphal, S. Schmidt, U. Flörke, Z. Anorg. Allg. Chem. 2009, 635, 216-220.

[25] a) S. Schmidt, S. Schulz, D. Bläser, C. Wölper, Main Group Metal Chem 2012, 35, 35-40; b) S. Schulz, S. Schmidt, D. Bläser, C. Wölper, Z. Anorg. 
Allg. Chem. 2012, 638, 1705-1710; c) S. Schmidt, B. Gutschank, S. Schulz, D. Bläser, R. Boese, C. Wölper, Eur. J. Inorg. Chem. 2011, 4464 4470; d) S. Schmidt, R. Schäper, S. Schulz, D. Bläser, C. Wölper Organometallics 2011, 30,1073-; e) S. Schmidt, S. Schulz, D. Bläser, R Boese, M. Bolte, Organometallics 2010, 29, 6097-6103; f) B. Gutschank, S. Schulz, D. Bläser, R. Boese, C. Wölper, Organometallics 2010, 29 6133-6136; g) B. Gutschank, S. Schulz, U. Westphal, D. Bläser, R. Boese, Organometallics 2010, 29, 2093-; h) M. Münch, U. Flörke, M. Bolte, S. Schulz, D. Gudat, Angew. Chem. 2008, 120, 1535-1537; Angew. Chem. Int. Ed. 2008, 47, 1512-1514.

[26] S. Schulz, S. Schmidt, D. Bläser, C. Wölper, Eur. J. Inorg. Chem. 2011 4157-4160.

[27] S. Schulz, R. Schäper, D. Bläser, C. Wölper, Z. Anorg. Allg. Chem. 2012 , $638,2102-2105$.

[28] Chelating coordination to $\mathrm{Zn}$, all delocalized and heteroatomic bonds defined as "any" Methyl groups in the backbone. 53 hits. $Z n-O$ average 2.01(3) $\AA$ (range: 1.953 to $2.073 \AA$ ) based on 97 bonds, $Z n-N$ average 1.99(5) $\AA$ (range: 1.919 to $2.098 \AA$ ) based on 97 bonds. Cambridge Structural Database, Version 5.38, see also: F. H. Allen, Acta Crystallogr. 2002, B58, 380-388.

[29] Delocalized and bonds to heteroatoms chosen to be of „any“ type. 7 hits $\mathrm{Zn}-\mathrm{O}$ of four-membered ring 2.126(16) $\AA$ (range: 2.106 to $2.15 \AA$ ).

[30] K. A. Gerling, N. M. Rezayee, A. L. Rheingold, D. B. Green, J. M. Fritsch, Dalton Trans. 2014, 43, 16498-16508.

[31] D. Barbier-Baudry, A. Bouazza, C. H. Brachais, A. Dormond, M. Visseaux, Macromol. Rapid Commun. 2000, 21, 213-217.

[32] M. K. Kiesewetter, E. J. Shin, J. L. Hedrick, R. M. Waymouth, Macromolecules 2010, 43, 2093-2107.

[33] F. Nederberg, E. F. Connor, M. Möller, T. Glauser, J. L. Hedrick, Angew. Chem. 2001, 113, 2784-2787; Angew. Chem. Int. Ed. 2001, 40, 2712 2715.

[34] H. F. Holtzclaw Jr., J. P. Collman, R. M. Alire, J. Am. Chem. Soc. 1958, 80, 1100-1103.

[35] G. M. Sheldrick, Acta Crystallogr. Sect. A 1990, 46, 467-473.

[36] a) G. M. Sheldrick, SHELXL-2014, Program for the Refinement of Crystal Structures University of Göttingen, Göttingen (Germany) 2014. See also: b) G. M. Sheldrick, Acta Crystallogr. Sect. A 2008, 64, 112-122; c) shelXle, A Qt GUI for SHELXL, C. B. Hübschle, G. M. Sheldrick, B. Dittrich, J. Appl. Cryst. 2011, 44, 1281-1284.

[37] PLATON/SQUEEZE, P. van der Sluis, A. L. Spek, Acta Crystallogr. 1990, A46, 194-201. 


\section{Entry for the Table of Contents}

\section{COMMUNICATION}

Five homo - and heteroleptic zinc ketoiminate complexes containing the sterically less demanding N,Ochelating MeNacac ligand are synthesized and their structures in solution and in the solid state investigated. In addition, their technical application as catalysts in ring-opening polymerization (ROP) of rac-lactide in $\mathrm{CDCl}_{3}$ solution at ambient temperature was studied.

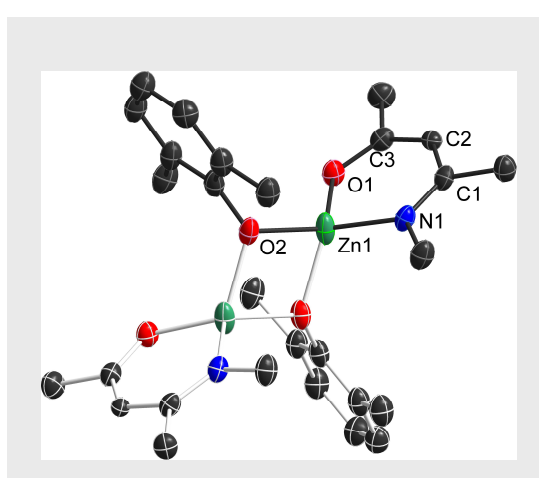

Lactide Polymerization

P. Steiniger, P. M. Schäfer, C. Wölper, J. Henkel, A. N. Ksiazkiewicz, A. Pich, S. Herres-Pawlis and S. Schulz*

Page No. - Page No.

Synthesis, structures and catalytic activity of homo- and heteroleptic ketoiminate zinc complexes in lactide polymerization 


\section{DuEPublico}

This text is made available via DuEPublico, the institutional repository of the University of Duisburg-Essen. This version may eventually differ from another version distributed by a commercial publisher.

DOI: $\quad$ 10.1002/ejic.201800504

URN: urn:nbn:de:hbz:464-20201218-094806-7

This is the peer reviewed version of the following article: Eur. J. Inorg. Chem. 2018, 36, 4014-4021, which has been published in final form at: https://doi.org/10.1002/ejic.201800504 